\title{
Analysis of the Effect of CEPA on FDI to Mainland China from Hong Kong
}

\author{
Xiaoxiao Wang \\ School of Economics, Jinan University, Guangzhou, China \\ Email: wxx3285636@163.com
}

Received 31 March 2016; accepted 26 April 2016; published 29 April 2016

Copyright (C) 2016 by author and Scientific Research Publishing Inc.

This work is licensed under the Creative Commons Attribution International License (CC BY). http://creativecommons.org/licenses/by/4.0/

(c) (i) Open Access

\begin{abstract}
Regional economic integration has got great achievements both in practice and theory since 1980s, which promotes the progress of the world economic liberalization. Besides the trade creation and diversion effect which had been researched widely, regional economic integration agreement also would create investment among members, and this dynamic investment effect now has been the main factor which pushes the progress of integration. Based on DID model and Gravity Model, this paper examines the influence of CEPA on FDI to Mainland China from Hong Kong by setting matched group, using 1998-2013 FDI from Hong Kong as sample. The conclusion is that CEPA and its supplemental agreements play a positive role on attracting Hong Kong FDI to Mainland China. With the transformation of development model in Mainland China, Hong Kong will invest more capital in knowledge-intensive Service industries in the future.
\end{abstract}

\section{Keywords}

CEPA, FDI, Regional Economic Integration, Investment Effect

\section{Introduction}

Due to the promotion from both developing and developed countries, such as the progresses of free trade areas in China and TPP negotiations dominated by the U.S.A., regional economic integration develops rapidly. To cater to this trend, Mainland China and Hong Kong officially signed "Closer Economic Partnership Arrangement" in June 29, 2003, and then the agreement came into effect in 2004. CEPA is not only a free trade area agreement under the WTO framework and further open to Hong Kong, but also has an ultimate goal to form economic alliance similar to European Union. CEPA is the first regional economic integration that Hong Kong joins in, and it means the economic cooperation between Mainland China and Hong Kong going deeper by more economically opening. For completing the details of basic agreement, ten supplemental agreements had been signed from 
2004 to 2013. This progressive development model of CEPA can ensure its influence in a long time, meanwhile provides a new way improving global economic integration.

CEPA and its supplemental agreements include three main aspects as follows: the first part is to eliminate trade barriers; the second part is to expand trade in Service industries; the third part is to facilitate trade and investment. The academic research has paid attention to the first and second parts much more than the last one before because of the data deficiency and method choosing. As the existing researches of CEPA are almost qualitative examination and even quantitative analysis are still about trading in goods, the researches about service trade and investment are extremely scarce, although service trade usually carries out through investing abroad, especially FDI. Whether the agreement of regional economic integration will promote FDI or not has not been empirically tested, while evaluating this effect by quantitative method can help us develop the investment theories of regional economic integration. Not only in theory but also in practice CEPA has great value, such as further liberalization in Services industry would make China's markets more competitive and productive, it would change the economy downward trend and provide new power for economic growth. In conclusion, leading the Hong Kong capital into Mainland Service industry through FDI could take full advantage of competitive edge and bring a high investment return back in Hong Kong. Though policy influence is hard to evaluate, but thanks to DID model, in this paper we can examine it by setting matched group, and using 1998-2013 FDI from Hong Kong to many other areas as sample. Considering of the policy basis and realistic demand changing, the FDI may exist tendency variation since 2004, and if true, that will be a strong evidence of investment effects of CEPA.

\section{The Influence of Regional Economic Integration Agreement on FDI}

With the development of economic globalization, FDI (Foreign Direct Investment) becomes an important link to promote world economic integration. Thus for catching up the developed countries, developing countries in particular focus on attracting FDI by Launching various preferential policies and motivators. These motivators are not limited to taxes and fees reducing, but also include land supply and labor education, etc. China also has stressed the importance of attracting foreign investment since put forward "open-door police" in 1978 which gradually expanded the scope of the investment. Based on the capital and advanced technology flowing in, the high economic growth of China gives a big shock to developed countries. In this respect, Chinese future economic reform in supply side which is important to structural adjustment also needs reasonably using FDI.

The volume of FDI absorbed by China is always the biggest in developing countries before 2014, only second to America. In 2014, China surpassed the US as the world's largest host country for foreign investment by attracting more than $\$ 128$ billion, which accounted for $10.2 \%$ of total global FDI that year. This provided a concrete manifestation of China's great investment environment.

The source of foreign capital flowing into China is very wide, including the world's major developed countries and some developing countries. But looking at the annual data, Hong Kong is undoubtedly the most important one.FDI from Hong Kong accounted for more than $50 \%$ of the total in a long time, even in the Asian financial crisis in 1997 this ratio was still over 40\%, which undoubtedly indicated its persistence and stability. Chinese provinces such as Beijing, Shanghai, Guangdong are the most active ones in attracting FDI, and in these provinces the total amount of FDI from Hong Kong always rank first since 1980s. This fully shows Hong Kong is the most important and representative FDI resource area for Mainland China, therefore, the study of its investment trend would further enhance the level of attracting investment. FDI from Hong Kong accounting for the total amount of foreign capital absorbed in mainland is shown in Figure 1.

The main purpose of regional economic integration is reallocating the resource among members through trade, investment, population movement or other methods to improve the general welfare of organization. Researches about this phenomenon started from 1950s, then the concept of regional economic integration had been widely quoted after being presented (Balassa, 1962). At that time, the emphasis of research was the type, basic theories and impact of regional economic integration, but scholars have conducted deep studies mainly on trade, however the studies on investment were very limited.

Taking example by trade creation and trade diversion theory, Kindleberger (1966) [1] proposed "investment creation" and "investment diversion" theory. After his contribution, the theoretical researches of investment creation and diversion effect caused by regional economic integration enriched quickly in company with empirical studies. In theoretical research, it mainly discussed the mechanism of action of the effect under regional economic integration. Baldwin, R. E., Forslid, R. \& Haaland, J. (1995) [2] first established a political economy 


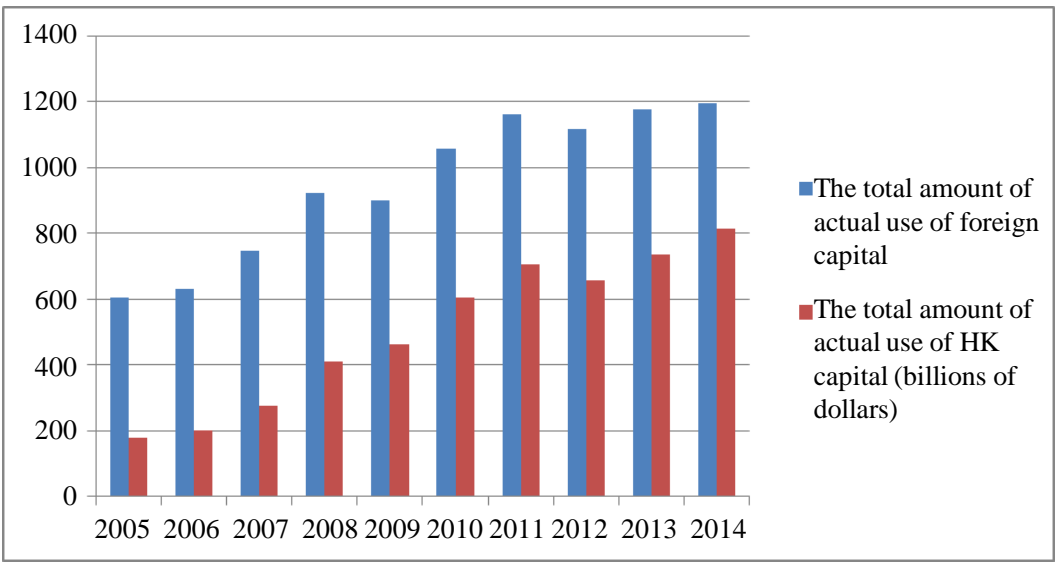

Data sources: "China Statistical Abstract"

Figure 1. 2005-2014 The total amount of actual use of foreign capital.

model to analyze the determinants of bilateral investment agreements and their impact on members and nonmembers, later Shabtai Donnenfeld (2003) [3], Barthel, FE Neumayer (2012) [4] also conducted a similar study. Neumayer (2014) [5] further discussed the agreements that contain strict provisions related to FDI could affect FDI flowing to developing countries or not. He proposed investment provisions containing strict bilateral investment agreements having more chances to stimulate investment inflow than those not contain strict provisions. In view of this fact, countries that have signed bilateral investment agreements would introduce more strict investment dispute settlement provisions (ISDS) and advance the establishment of the national treatment clause (Berger, A., M. Busse, P. Nunnenkamp and M. Roy, 2013; Eric Neumayer, Peter Nunnenkamp, Martin Roy, 2014) [6].

In empirical studies, Kindleberger (1966) believed that companies in member countries would carry out direct investment to other members to expand the scale of production considering of the economies of scale, trade costs, etc. In 1980s, the researches began to analyze capital flowing in NAFTA (Blomstrom, M. et al., 1998; Blonigen, B. \& Davies, R., 2000; Waldkirch, A., 2003) [7]. North American Free Trade Agreement (NAFTA) is a typical regional economic integration agreement between the developed and developing countries, while the agreement also includes the provisions to expand investment as CEPA, especially emphasis on national treatment and most-favored-nation-treatment. Before Mexico entered into NAFTA, the investment from the United States and Canada only took account for 38\% in the total investment, although there had a natural geographical advantage. Just seven years after the agreement came into effect, this proportion of total amount of investment in Mexico reached more than 80\% (UNCTAD, 2002). Chinese scholars pointed that Mexico got greater gains in NAFTA so China should learn from its experience to use various methods to strengthen economic integration with neighboring countries (Lan, 2007) [8]. With the development of economy in Asian, scholars shifted their focus on economic integration among Asian countries as ASEAN Free Trade Area (Bende-Nabende, A., Ford, J.L. and Slater, J.R, 1999) [9]. Guo (2009) [10] claimed that the economic integration in ASEAN by investment facilitation, sensitive list (similar to the negative list) and other policies would induce intra-ASEAN investment flows increasing, except the year 1997 and 2008 of financial crisis, the data presented obvious growth momentum of foreign investment flowing. Other Asian researches also involved Japan and South Korea free trade agreement, etc (Han, Yeo, Yoon, and Yoo, 2004) [11].

After CEPA was signed, domestic scholars began to research the trade transformation first, especially for key provinces as Guangdong, Beijing and Shanghai, then some study change to focus on trade in Service industry (Sun, 2004) [12]. As the importance of FDI became more visible, academic community conducted many researches to analyze the factors affecting FDI (Yun, 2006 [13]; Chen, 2012 [14]). But because of the serious data missing and hard model choosing, it has no conditions to use quantitative for analysis at that time, so these studies about investment under CEPA were given priority to theory, which induced the empirical analysis appearing rarely in the paper of Wu (2008) [15] and Wang (2012) [16], etc. Despite the fundamental purpose of signing bilateral investment agreement is attracting direct investment, in fact whether the bilateral agreements could stimulate FDI is uncertain (Swenson, 2005) [17]. The research of Wang (2013) [18] also showed that the agree- 
ments of CEPA only focused on service industry market access and investment facilitation, so the institutional safeguard was weaker than NAFTA. This article will use the national investment statistics provided by Hong Kong and the provincial data in mainland, combined with the DID model to supply this research vacancy.

\section{The Empirical Study of CEPA on Attracting FDI from Hong Kong to Mainland China}

The content of CEPA about investment facilitation could be summarized as follows: to ease strict access conditions, represented by the financial services industry; to intensify intellectual property protection; to strengthen mutual recognition of professional qualifications. According to the industry distinction in Hong Kong, the situation that Hong Kong invests in service industry and manufacturing is shown in Figure 2.

We witnessed major industries that HK capital invested in experiencing a gradual increase after CEPA came into effect. The stock of Service industry in 2013 grew as 3.6 times as in 2004, meanwhile the amount of investment stock reach $\$ 3.11$ trillion from $\$ 864.3$ billion; The stock of Manufacturing investment in 2013 grew as 2.3 times in as in 2004, while the stock of investment grew from $\$ 273.7$ billion to $\$ 624.8$ billion. No matter observing from the overall or industries data, after CEPA became effective, the amount of investment from Hong Kong to the mainland was growing.

This was in conformity with the scholars' study. Hua (2008) [19] pointed that not only the investment from Hong Kong to the mainland was increasing under CEPA, but the industry distribution became more varied as well.

\subsection{The Introduction of Empirical Method and Data}

This article mainly uses DID model analyzing FDI flows. DID (difference in difference) model has widely used in all sorts of policy impact study in recent years, so it gets continuously innovation and development. The basic principle of DID is using control group simulating sample group without implementing new policy through the virtual variable settings (like physics sets up the frame of reference) compared with the sample group to reflect the new policy influence on the sample group. The simplest form of the DID model is the following:

$$
\ln F D I_{i j t}=\beta_{0}+\beta_{1} d u+\beta_{2} d t+\gamma d u * d t+\varepsilon_{i j t} .
$$

The dummy variable $d u=1$ means that they are sample group variables while $d u=0$ means control group varibles; another dummy variable $d t=1$ means the period after policy implementation while $d t=0$ means the period before. The impact on the sample group after policy implementation is

$E(d t=1, d u=1)-E(d t=0, d u=1)=\beta_{0}+\beta_{1}+\beta_{2}+\gamma-\left(\beta_{0}+\beta_{1}\right)=\beta_{2}+\gamma$; the impact on the control group after policy implementation is $E(d t=1, d u=0)-E(d t=0, d u=0)=\beta_{0}+\beta_{2}-\beta_{0}=\beta_{2}$. The minus between the two, namely $\gamma$, the coefficient of $d u * d t$ is the net impact of police, also is the most important observation item in this paper.

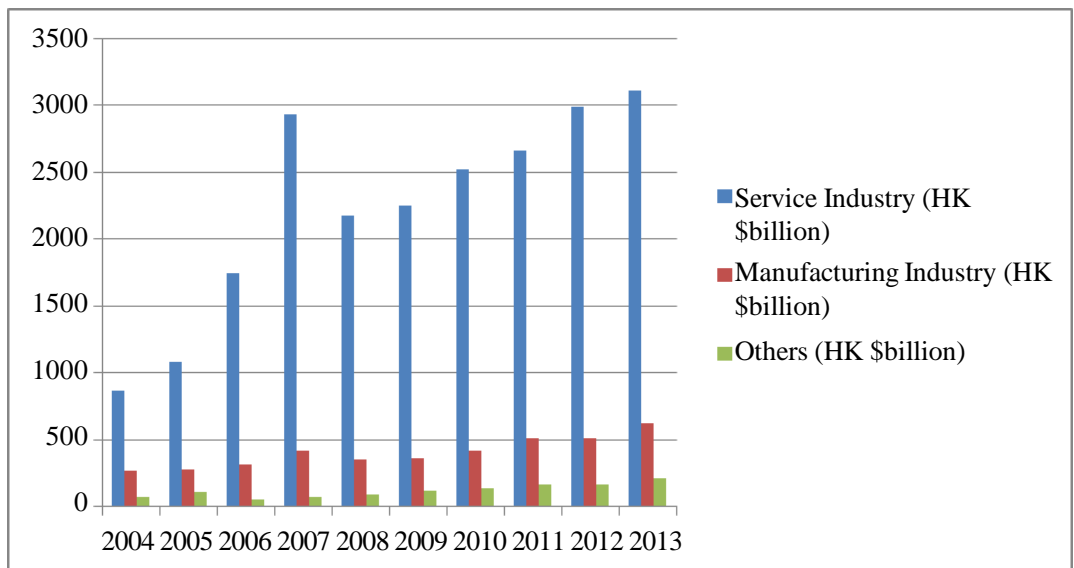

Data source: Hong Kong Census and Statistics Department

Figure 2. 2004-2013 Hong Kong investment stock in Mainland. 
This article selects Australia, Britain, the United States and Canada, Bermuda and Singapore as the control group members, because these countries are always the main investment destination countries of Hong Kong and have the perfect data statistics. At same time in order to improve the degree of fitness, this paper introduces the gravity model into the DID model.

The gravity model first used in the analysis of the international trade appeared in the 1950s, which concluded the core variables like GDP and Distance. After continuous developed by bring different kinds of new variables to improve applicability, gravity model was widely used in the analysis of trade and investment. Domestic scholars widely upgraded gravity model for empirical research in 1990s. Pan (2004) [20] earlier researched the system impacting on bilateral trade from institution by gravity model, and he pointed out that the wage policy influenced Chinese bilateral trade obviously, which was a typical field of gravity model researching. Zhao and Lin (2008) [21] analyzed the ASEAN countries and China's agricultural products trade by gravity model to prove the great potential for both sides. When using the gravity model in this paper, we choose the classical regression equation. Typically the gravity model contains a virtual variable to express different areas, but is omitted here due to dummy variable in DID model introduced.

Comprehensively thinking of the requirement of DID model and the gravity model, this paper chooses to set the following model:

$$
\begin{aligned}
\ln F D I_{i j t}= & \beta_{0}+\beta_{1} d u+\beta_{2} d t+\gamma d u * d t+\theta_{1} \ln P G D P_{i t}+\theta_{2} \ln P G D P_{j t} \\
& +\theta_{3} \ln T P_{i t}+\theta_{4} \ln T P_{j t}+\theta_{5} \ln D I S_{i j}+\theta_{6} \ln I N V+\varepsilon_{i j t}
\end{aligned}
$$

The dependent variables of DID model are expressed in the natural logarithm for easy comparison and offering better interpretation considering of the differences of statistic units in each country.

$I$ means $i$ country or area; $J$ means $j$ country or area; $t$ is the time variable. $F D I_{i j t}$ represents $i$ region in period $t$ gives $j$ country's direct investment, where the amount of FDI estimated by the market value method. According to international standards, calculating FDI through market value method instead of book value is more effectively because the market value represents the realizable assets now, therefore it will be more persuasive. The dummy variable $d u=0$ represents control group variables while $d u=1$ means sample group variables. As CEPA came into effect in 2004, the time dummy $d t=0$ means period before 2004, and $d t=1$ means after 2004 . These are the basic variables of DID model.

Investment between the two countries are affected by the two countries' GDP, in view of the scale differences between sample countries, we select real GDP growth rate as variable, namely PGDP, could be more objective here.

The larger the populous is, the more demand for commodities exists, so investment demand is relatively high. We set variable TP in this paper representing total population. Then $D$ is the distance variable, estimated by the distance between the two capitals.

Inv means the stock of investment. For stock Investment may carry on for a long time, therefore, it may haves great influence in the future. The residual term is $\varepsilon$.

The core data of this article is foreign direct investment statistical data in Hong Kong from 1998 to 2013 and historical data from China Statistical Yearbook, which is the most comprehensive data ensuring continuity and consistency. Distance data comes from Google Earth, and other data come from the WTO’s official database.

\subsection{National Data, Empirical Results and Discussion}

In specific processing, this paper chooses Excel 2010 as statistics and drawing software, Stata 11.0 as measurement software. This paper uses OLS panel regression model, and the specific information is shown in Table 1 (1).

The $\gamma$ is positive value seen from the empirical results and is significant under the condition of *. That makes us believe CEPA actually plays an obvious role on promoting FDI flows into Mainland China from $\mathrm{HK}$. Although the traditional industries in Mainland China now gradually lose competitiveness and have moved to southeast Asia and other regions due to the increasing labor cost and environmental cost along with the appreciation of RMB in recent years, the growing demand for high-level Service industry likes communications industry and finance industry still have strong appeal for Hong Kong investors. Figure 3 is the proportion of top three industries (information and communication industry; investment company, realestate, professional and commercial services industry; manufacturing industry) Hong Kong investing in mainland accounting for its total outward investment: 
Table 1. Regression results.

\begin{tabular}{|c|c|c|c|}
\hline & (1) & (2) & (3) \\
\hline$\beta_{0}$ & $\begin{array}{c}-23.905 \\
(0.444)\end{array}$ & $\begin{array}{c}2.764^{* * *} \\
(0.000)\end{array}$ & $\begin{array}{c}-68.806^{* * *} \\
(0.000)\end{array}$ \\
\hline$\beta_{1}, d u$ & $\begin{array}{l}2.003^{* * * *} \\
(0.003)\end{array}$ & $\begin{array}{l}1.987^{* * *} \\
(0.000)\end{array}$ & $\begin{array}{l}-0.125 \\
(0.671)\end{array}$ \\
\hline$\beta_{2}, d t$ & $\begin{array}{l}-0.120 \\
(0.629)\end{array}$ & $\begin{array}{c}0.111 \\
(0.431)\end{array}$ & $\begin{array}{c}-0.431^{* * *} \\
(0.002)\end{array}$ \\
\hline$\gamma, d u * d t$ & $\begin{array}{c}0.685^{*} \\
(0.074)\end{array}$ & $\begin{array}{l}0.711^{*} \\
(0.056)\end{array}$ & $\begin{array}{l}0.621^{* * * *} \\
(0.000)\end{array}$ \\
\hline $\ln P G D P_{i t}$ & $\begin{array}{l}1.767^{*} \\
(0.080)\end{array}$ & - & $\begin{array}{c}0.530 \\
(0.573)\end{array}$ \\
\hline $\ln P G D P_{j t}$ & $\begin{array}{l}-0.527 \\
(0.848)\end{array}$ & - & $\begin{array}{l}-1.007 \\
(0.491)\end{array}$ \\
\hline $\ln T P_{i t}$ & $\begin{array}{c}4.155 \\
(0.385)\end{array}$ & - & $\begin{array}{c}11.432^{* * *} \\
(0.000)\end{array}$ \\
\hline $\ln T P_{j t}$ & $\begin{array}{l}-0.024 \\
(0.393)\end{array}$ & - & $\begin{array}{l}-0.013 \\
(0.751)\end{array}$ \\
\hline $\ln D I S_{i j}$ & $\begin{array}{l}-0.018 \\
(0.905)\end{array}$ & - & $\begin{array}{c}-0.295^{* * * *} \\
(0.006)\end{array}$ \\
\hline $\ln I N V$ & $\begin{array}{c}0.040 \\
(0.763)\end{array}$ & - & - \\
\hline$R^{2}$ & 0.634 & 0.616 & 0.492 \\
\hline
\end{tabular}

Notes: ${ }^{*},{ }^{* * * * *}$ respect significant in $10 \%, 5 \%$ and $1 \%$ level.

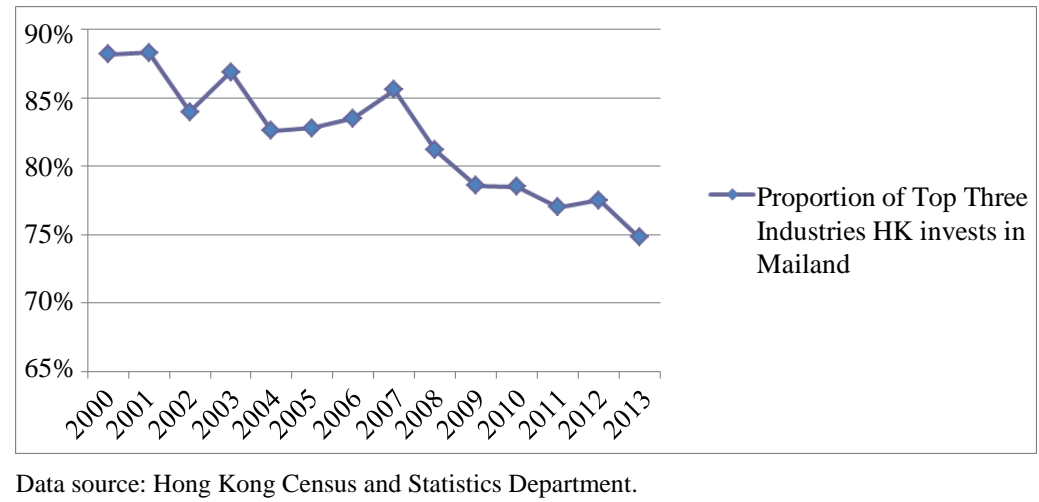

Figure 3. Top three industries HK invests in Mainland.

Hong Kong's real GDP growth rate is significant means GDP growth improving the ability of Hong Kong's foreign investment. The influence of the investment stock is not significant indicating that the direction of new investment is not just to expand the original industry again, but transfer to more other industries. In order to verify the reliability of the conclusion, we return to test Formula 1. The conclusion is in Table 1 (2), and this empirical results supports all above conclusion.

\subsection{Provincial Data, the Empirical Results and Discussion}

Considering of the amount of data in countries is a little small, we further join provincial data into to construct the robust test by DID model. The new formation is as follows:

$$
\begin{aligned}
\ln F D I_{i j t}= & \beta_{0}+\beta_{1} d u+\beta_{2} d t+\gamma d u * d t+\theta_{1} \ln P G D P_{i t}+\theta_{2} \ln P G D P_{j t} \\
& +\theta_{3} \ln T P_{i t}+\theta_{4} \ln T P_{j t}+\theta_{5} \ln D I S_{i j}+\varepsilon_{i j t}
\end{aligned}
$$


Table 2. The provincial data list.

\begin{tabular}{cccc}
\hline Ranking & Province & Ranking & Province \\
\hline 1 & Jiangsu & 7 & Shandong \\
2 & Liaoning & 8 & Henan \\
3 & Guangdong & 9 & Sichuan \\
4 & Shanghai & 10 & Chongqing \\
5 & Tianjin & 11 & Anhui \\
6 & Zhejiang & 12 & Beijing \\
\hline
\end{tabular}

The variables' meaning is the same as above besides $D$ is defined as the distance from Hong Kong to the provincial capital. At the same time, to avoid some provinces attracting too little amount of FDI in some years leads to unusual value, according to "The 2014 China Urban FDI Attraction Report”, we choose Chinese provinces in top ten of the report as sample group. These provinces attract the most foreign capital in Mainland China, and Table 2 shows the list:

Relevant historical provinces data this paper uses is citied at the provincial level statistical yearbook while the rest data is the same as above. The result is shown in Table 1 (3). Variable $\gamma$ is still positive under the more stringent condition of ***, so it gives more powerful illustrates ensuring the positive effect of CEPA. Meanwhile, the variable $\mathrm{D}$ is becomes significant reflects that provincial situation has some differences, thus the impact from CEPA to different provinces is worth deeper studying in the future.

To sum up, CEPA brings obvious positive effect in the mainland on attracting FDI from Hong Kong, what is glad to be seen on both sides. We could further strengthen relevant research in a more micro level to promote development and optimization of CEPA.

\section{Conclusions}

With the rapid economic development in China Mainland, residents' disposable income has been improved obviously. According to economic principle, the level of demands in product and service will be increased as well, which may form giant emerging markets.

Moreover, the pace that China merges into the world economy will never stop, such as the new wave of free trade zone established in Tianjin, Shanghai, Guangdong and Fujian. These places bring out negative list to ease investment restrictions and improve the extent of openness to raise attractiveness for foreign investors. In addition, China has 20 FTAs under construction, involving 32 countries and regions. Among them, 12 free trade agreements in 20 countries or regions have been signed.

But CEPA and its supplementary agreement are a comprehensive economic integration agreement, thus they take much competitive edge to Hong Kong. So, better taking advantage of the convenience brought by CEPA to expand the investment scope is increasingly important for Hong Kong economic development.

With the continuous expansion of opening field, the investment facilitation will be the key process of next supplement of CEPA. This paper shows that CEPA actually encourages Hong Kong to invest in Mainland China by many methods like expanding market access, especially in Service industry. So doing deeper researches can help us implement a more accurate interpretation of investment policies and regimes, which can provide an important reference for China's next economic integration process. At the same time, since there are huge differences in the development of each province in Mainland China, they should take advantages of their own endowment and avoid cutthroat competition or low-level investment coming from Hong Kong.

\section{References}

[1] Kindleberger, C.P. (1996) European Integration and the International Corporation. Columbia Journal of World Business, 1, 383-390.

[2] Baldwin, R.E., Forslid, R. and Haaland, J. (1995) Investment Creation and Investment Diversion: Simulation Analysis of the Single Market Programme. NBER Working Paper No. 534.

[3] Donnenfeld, S. (2003) Regional Blocs and Foreign Direct Investment. Review of International Economics, 11, 770- 
788. http://dx.doi.org/10.1046/j.1467-9396.2003.00417.x

[4] Barthel, F. and Neumayer, E. (2012) Competing for Scarce Foreign Capital: Spatial Dependence in the Diffusion of Double Taxation Treaties. International Studies Quarterly, 56, 645-660. http://dx.doi.org/10.1111/j.1468-2478.2012.00757.x

[5] Berger, A., Busse, M., Nunnenkamp, P. and Roy, M. (2013) Do Trade and Investment Agreements Lead to More FDI? Accounting of Key Provision inside the Black Box. International Economics and Economic Policy, 10, 1-26. http://dx.doi.org/10.1007/s10368-012-0207-6

[6] Neumayer, E., Nunnenkamp, P. and Roy, M. (2014) Are Stricter Investment Rules Contagious? Host Country Competition for Foreign Direct Investment through International Agreements. WTO Working Paper.

[7] Blomstrom, M., et al. (1998) Regional Economic Integration and Foreign Direct Investment: The North American Experience. Working Paper Series in Economics and Finance No. 269.

[8] Tian, L. (2011) Analysis on the Economic Effect of North American Free Trade Agreement. PhD Thesis, Jilin University.

[9] Bende-Nabende, A., Ford, J.L. and Slater, J.R. (1999) The Impact of FDI on the Economic Growth of the ASEAN-5 Economies, 1970-1994: A Comparative Dynamic Multiplier Analysis from a Small Model with Emphasis on Liberalisation. Department of Economics, University of Birmingham in Its Series Discussion Papers with Number 91-18.

[10] Guo, H. (2009) ASEAN Regional Economic Integration and its Effects on Trade and Foreign Direct Investment. Asian-Pacific Economy, No. 5, 38-41.

[11] Han, D.-G., Yeo, T.-D., Yoon, Y.-M. and Yoo, S. (2004) How Will the China-Japan-Korea FTA Affect the Inward FDI to Korea. Sungkyunkwan University Working Paper, 3-4, 101-129.

[12] Sun, W. (2004) Hong Kong Investment Prospects under CEPA. Management World, No. 12, 134-135.

[13] Yuan, C.P. and Wu, K.H. (2006) Evolution and Spreading Effect on Direct Investment Route among Guangdong, Hong Kong and Macaw-Based on the Convenience of Direct Investment Prospective. Journal of Guangdong University of Finance, 21, 70-78.

[14] Chen, E. (2012) Opportunities and Challenges Faced by the New Government of Hong Kong. Study of Contemporary Hong Kong and Macao, No. 7, 62-72.

[15] Wu, X.J. and Wang, Y.Y. (2008) An Empirical Analysis of Factors for Attracting FDI from Hong Kong to Mainland China. Journal of Hunan University, No. 3, 47-50.

[16] Wang, J. (2012) Analysis of Hong Kong Direct Investment to the Mainland with the Gravity Model under the CEPA Framework. Contemporary Economy and Management, 34, 19-23.

[17] Swenson, D.L. (2005) Why Do Developing Countries Sign BITs? U.C. Davis Journal of International Law and Policy, 12, 437-459.

[18] Wang, N. (2013) Thinking of Investment Agreement between Mainland China and Hong Kong under CEPA Frame. Journal of Yunnan University Law Edition, 26, 139-155.

[19] Hua, X.H. and Yang, L.Q. (2008) The Evaluation of CEPA. International Trade, No. 11, 38-45.

[20] Pan, X.D., Liao, J.Z. and Lai, M.Y. (2014) Institutional Factors and the Bilateral Trade. World Economy, No. 5, 78-85.

[21] Zhao, Y.L. and Lin, G.H. (2008) Analysis of the Bilateral Trade Flows and the Potential for Trade of Agricultural Products between China and the 10 ASEAN Countries. Journal of International Trade, No. 12, 23-56. 